\title{
Pengembangan Multimedia Pembelajaran Interaktif Mata Pelajaran IPA Untuk Siswa SD Kelas V
}

\author{
Gede Cris Smaramanik Dwiqi \\ Program Studi Teknologi Pendidikan, Universitas Pendidikan Ganesha \\ gede.cris.smaramanik@undiksha.ac.id \\ I Gde Wawan Sudatha \\ Program Studi Teknologi Pendidikan, Universitas Pendidikan Ganesha \\ igdewawas@undiksha.ac.id
}

Adrianus I Wayan Ilia Yuda Sukmana

Program Studi Teknologi Pendidikan, Universitas Pendidikan Ganesha aiwiy-sukmana@undiksha.ac.id

\author{
A R T I C L E I N F O \\ Article history: \\ 1 Juli 2020 Received in \\ revised form \\ 30 Agustus 2020 \\ Accepted 28 September 2020 \\ Available online \\ 30 September 2020 \\ Kata Kunci \\ Pengembangan, Multimedia \\ Pembelajaran Interaktif. \\ Keywords: \\ Development, Interactive \\ Learning Multimedia.
}

\begin{abstract}
AB S T R A K
Penelitian pengembangan ini dilaksanakan karena kurangnya pemanfaatan media digital oleh pendidik dalam melakukan proses pembelajaran sehingga peserta didik kurang tertarik dalam belajar dan menyebabkan menurunnya hasil belajar peserta didik secara signifikan. Dilaksankannya penelitian pengembangan ini yaitu bertujuan untuk mendeskripsikan rancang bangun pengembangan multimedia pembelajaran interaktif dan validitas multimedia pembelajaran interaktif. Penelitian ini merupakan penelitian pengembangan dengan model penelitian pengembangan ADDIE (analyze, design, development, implementation, evaluation). Data yang dikumpulkan adalah data kuantitatif dan data kulitatif dengan mengunakan 3 metode pengumpulan data yaitu
\end{abstract} metode observasi, metode wawancara, dan metode kuesioner. Hasil Penelitian menunjukkan 1) Rancang bangun pengembangan multimedia pembelajaran interaktif meliputi tiga tahapan yaitu: (a) analisis kebutuhan, (b) desain, (c) pengembangan dan implementasi, valid dengan: (a) hasil review ahli mata pelajaran dengan kualifikasi sangat baik $(97,33 \%)$, (b) hasil review ahli desain pembelajaran dengan kualifikasi sangat baik (100\%), (c) hasil review ahli media pembelajaran dengan kualifikasi sangat baik (98\%), (d) hasil uji coba perorangan dengan kualifikasi sangat baik $(96,67 \%$ ), (e) hasil uji coba kelompok kecil dengan kualifikasi sangat baik $(96,85 \%)$. 2) Jadi berdasarkan uji validitas pengembangan multimedia pembelajaran interaktif menunjukkan hasil yang efektif didalam meningkatkan hasil belajar IPA sehingga layak untuk digunakan dalam proses pembelajaran. 
design, (c) development and implementation, valid by: (a) The review results of subject matter experts with very good qualifications (97.33\%), (b) The results of the review of instructional design experts with very good qualifications (100\%), (c) The results of the reviews of instructional media experts with very good qualifications (98\%), (d) The results of individual trials with very good qualifications. good $(96.67 \%)$, (e) small group trial results with very good qualifications $(96.85 \%)$. 2). In conclusion, based on the validity test of the development of interactive learning multimedia, it shows effective results in improving science learning (IPA) outcomes. Thus, it is suitable for use in the learning process.

\section{PENDAHULUAN}

Era digital pada saat ini membawa dampak yang sangat besar bagi kehidupan manusia sehingga tidak dapat dipandang sebelah mata khususnya oleh dunia pendidikan di Indonesia (Widiara, 2018). Pada era digital peranan teknologi dapat dimanfaatkan secara maksimal untuk menunjang proses pendidikan khususnya dalam proses pembelajaran, sehingga dapat membantu seorang pendidik didalam mengemas dan menyajikan informasi kepada peserta didik. Pemanfaatan media dalam pembelajaran dapat membangkitkan keinginan peminat baru, meningkatkan motivasi dan rangsangan kegiatan belajar, dan bahkan berpengaruh secara psikologis kepada anak, (Putra dan Ishartiwi, 2015). Tetapi penggunaan teknologi digital didalam menunjang proses pembelajaran belum diterapkan secara maksimal karena beberapa kendala seperti memilih ataupun merancang media pembelajaran yang sesuai dengan materi pembelajaran, mengoperasikan media pembelajaran berbasis IT, dan lain-lain. Hal tersebut menyebabkan kurang menariknya proses pembelajaran, sehingga menyebabkan kurangnya pengalaman belajar siswa, dengan demikian tujuan pembelajaran tidak dapat tercapai dengan maksimal. (Rusdewanti dan Gafur, 2014)juga menyatakan bahwa permasalahan yang dihadapi sekolah dalam pemanfaatan media saat ini adalah kurang tersedianya media pembelajaran interaktif di sekolah selai itu masih banyaknya guru yang belum mampu membuat media pembelajaran interaktif. Pernyataan tersebut diperkuat dengan hasil penelitian dari (Abdullah, 2016) yang menyatakan bahwa kreativitas guru suatu mata pelajaran dalam memanfaatkan media pembelajaran belum begitu maksimal. Guru hanya menggunakan media berupa buku, papan tulis dan media pajang. Akan tetapi dalam merancang atau mendesain media sendiri yang berhubungan dengan materi pelajaran guru belum bisa melakukannya. Maka dengan demikian guru hanya memanfaatkan media yang ada di sekolah sedangkan untuk mengembangkannya guru belum optimal.

Berdasarkan pada hasil observasi dan wawancara yang telah dilakukan dengan guru kelas V di SD Negeri 1 Banjar Jawa, maka diperoleh informasi bahwa sumber belajar yang digunakan oleh guru dalam proses pembelajaran masih berupa bahan ajar cetak dan media yang digunakan guru hanya media konvensional saja, hal ini dikarenakan kurangnya kemampuan guru didalam mengembangkan media pembelajaran berbasis digital seperti media presentasi, video, animasi ataupun multimedia interaktif sehingga menyebabkan siswa cenderung bosan didalam mengikuti pembelajaran ditambah lagi pembelajaran yang bersifat abstrak. Jika pendidik tidak inovatif didalam menunjang proses pembelajaran maka akan berdampak pada hasil belajar siswa. Hasil belajar adalah pernyataan yang menentukan apa yang siswa tahu atau mampu lakukan sebagai hasil dari kegiatan belajar. Hasil belajar biasanya dinyatakan sebagai pengetahuan, keteram-pilan, atau sikap, (Elpira dan Ghufron, 2015). Hasil belajar juga merupakan tolak ukur untuk melihat keberhasilan peserta didik dalam menguasai materi pelajaran yang disampaikan selama pembelajaran, (Surya, 2017). 
Nilai rata-rata hasil UTS siswa kelas V pada mata pelajaran IPA tahun ajar 2019/2020 yaitu 75 akan tetapi masih terdapat 33 siswa dari 43 siswa yang mendapatkan nilai di bawah KKM. KKM Nasional yang harus dipenuhi oleh peserta didik yaitu 75. Berdasarkan dengan latar belakang permasalahan tersebut maka salah satu solusi yang dapat ditawarkan untuk dapat menarik perhatian siswa dalam belajar serta menciptakan suasana belajar yang menyenangkan sehingga dapat meningkatkan hasil belajar peserta didik adalah dengan mengembangkan media pembelajaran berbasis digital berupa multimedia pembelajaran interaktif.

Multimedia interaktif merupakan gabungan beberapa unsur media lain, antara teks, gambar, grafis, animasi, audio dan video, serta cara penyampaian interaktif yang dapat membuat suatu pengalaman belajar bagi siswa seperti dalam kehidupan nyata di sekitarnya, (Bardi dan Jailani, 2015). Vaughan (Jumasa dan Surjono, 2016) juga mengemukakan bahwa multimedia merupakan kombinasi dari teks, gambar, suara, animasi, dan video yang disampaikan melalui peranti komputer, elektronik, atau alat hasil rekayasa digital lainnya. Penggunaan multimedia interaktif dalam pembelajaran tentunya memiliki kelebihan yaitu: (1) sistem pembelajaran lebih inovatif dan interaktif; (2) pendidik akan selalu dituntut untuk kreatif dan inovatif dalam mencari terobosan pembelajaran; (3) mampu menggabungkan antara teks, gambar, audio, musik, animasi gambar atau video dalam suatu kesatuan yang saling mendukung guna tercapainya tujuan pembelajaran; (4) menambah motivasi peserta didik selama proses belajar mengajar hingga didapatkan tujuan pembelajaran yang diinginkan; (5) mampu menvisualisasikan materi yang selama ini sulit untuk diterangkan hanya sekedar dengan penjelasan atau alat peraga yang konvensional; dan (6) melatih peserta didik lebih mandiri dalam mendapatkan ilmu pengetahuan, Munir (Nazalin dan Muhtadi, 2016). Mardika (Rosita, 2015) juga berpendapat bahwa multimedia dalam proses belajar mengajar dapat digunakan dalam tiga fungsi yaitu: 1) multimedia dapat berfungsi sebagai alat bantu instruksional; 2) multimedia dapat berfungsi sebagai tutorial interaktif, misalnya dalam simulasi; 3) multimedia dapat berfungsi sebagai sumber petunjuk belajar, misalnya, multimedia digunakan untuk menyimpan serangkaianslide mikroskop atau radiograf. Sudjana (Rusdewanti dan Gafur, 2014) menyatakan bahwa multimedia bermanfaat dalam proses pembelajaran, maka menjadikan: (1) pengajaran lebih menarik perhatian siswa sehingga dapat menimbulkan motivasi belajar; (2) bahan pengajaran lebih jelas maknanya sehingga dapat dipahami oleh siswa dan memungkinkan siswa menguasai tujuan pembelajaran dengan baik; (3) metode mengajar lebih bervariasi; (4) siswa lebih banyak melakukan kegiatan belajar, sebab tidak hanya mendengarkan penjelasan guru tetapi ikut terlibat dalam aktifitas lain seperti mengamati, melakukan, mendemonstrasikan dan lain-lain. Jadi berdasarkan pada pendapat tersebut, maka disimpulkan bahwa multimedia pembelajaran interaktif merupakan media digital yang yang mengabungkan beberapa aspek media lain menjadi satu kesatuan seperti teks, gambar, suara, animasi, video dan interaktivitasnya dengan demikian multimedia akan dapat menarik minat siswa serta motivasi siswa dalam belajar sehingga siswa dapat menguasai materi dengan baik. Hal tersebut dibuktikan dengan penelitian yang dilakukan oleh (Riyadi dan Pardjono, 2014) yang menyatakan bahwa multimedia lebih efektif digunakan dalam pembelajaran untuk meningkatkan hasil belajar siswa jika dibanding dengan pembelajaran konvensional. (Widyatmojo dan Muhtadi, 2017) menyatakan bahwa multimedia pembelajaran dapat dikatakan sebagai media yang mempunyai potensi sangat besar dalam membantu proses pembelajaran. (Nugraha dan Muhtadi, 2015) menyatakan bahwa 
multimedia pembelajaran dinyatakan efektif didalam meningkatkan hasil belajar siswa. (Putri dan Muhtadi, 2018) juga berpendapat bahwa multimedia pembelajaran terbukti efektif untuk meningkatkan capaian hasil belajar kognitif siswa. Jadi berdasarkan pada beberapa temuan tersebut dapat disimpulkan bahwa multimedia pembelajaran interaktif terbukti memberikan dampak positif terhadap hasil belajar siswa.

Berdasarkan pemaparan diatas maka dapat dirumuskan tujuan dilaksankannya penelitian pengembangan ini yaitu untuk mendeskripsikan rancang bangun dan validitas multimedia pembelajaran interaktif pada siswa kelas V di SD Negeri 1 Banjar Jawa tahun ajaran 2019/2020. Dengan pengkolaborasian penggunaan media digital (multimedia interaktif) dalam proses pembelajaran akan menjadi alternatif yang dapat digunakan guru dalam mengembangkan dan menginovasikan pembelajaran yang kreatif dan inovatif sehingga dapat meningkatkan hasil belajar siswa.

\section{METODE PENELITIAN}

Penelitian pengembangan ini dilaksanakan pada tanggal 25 Maret 2020 hingga 25 Juni 2020 di SD Negeri 1 Banjar Jawa. Adapun subjek pada penelitian pengembangan ini yaitu, 1 orang ahli isi mata pelajaran, 1 orang ahli desain pembelajaran, 1 orang ahli media pembelajaran, 3 orang siswa untuk uji coba perorangan, dan 6 orang siswa untuk uji coba kelompok kecil. Prosedur penelitian pengembangan ini mengacu pada model ADDIE yang terdiri atas lima langkah yaitu, analyze, design, development, implementation, dan evaluation, (Trisiana, 2016; Uno, 2016). Model pengembangan ADDIE memiliki kelebihan karena pada semua tahapannya selalu melalui tahap evaluasi terlebih dahulu, sehingga dapat meminimalisir kesalahan ataupun kekurangan sekecil apapun sejak awal.

Metode pengumpulan data yang digunakan dalam penelitian pengembangan ini yaitu metode observasi, metode wawancara, dan metode kuesioner. Metode observasi merupakan suatu cara yang digunakan dalam melakukan penilaian dengan melakukan pengamatan secara langsung dan sistematis, (Agung, 2017). Data yang didapatkan dengan metode observasi akan lebih akurat dan sulit untuk dibantahkan karena melakukan pengamatan secara langsung ke lapangan sehingga data yang didapat sesuai dengan kenyataan atau real. Metode interview/wawancara merupakan suatu metode yang digunakan dalam mengumpulkan data dengan cara melakukan tanya jawab secara sistematis, dan hasil tanya jawab harus dicatat/direkam dengan teliti dan cermat, (Agung, 2017: 104). Metode kuesioner merupakan cara dalam mengumpulkan data dengan memberikan daftar pertanyaan kepada responden yang dijawab secara tertulis (Agung, 2017: 106). Metode ini digunakan untuk mengukur kelayakan produk E-modul dari para ahli (ahli mata pelajaran, ahli desain pembelajaran, dan ahi media pembelajaran).

Penelitian pengembangan ini menggunakan beberapa instrumen dalam mengumpulkan data untuk penelitian, diantaranya: lembar observasi, lembar wawancara, dan lembar kuesioner. Lembar observasi digunakan untuk mengetahui fasilitas belajar yang dimiliki sekolah dan siswa, serta melihat proses pembelajaran siswa. Adapun kisi-kisi lembar observasi pada penelitian pengembangan ini terdapat pada tabel 1 .

Tabel 1. Kisi-kisi Lembar observasi

\begin{tabular}{cl}
\hline No & \multicolumn{1}{c}{ Pernyataan } \\
\hline 1 & Apakah bapak/ibu bias mengoprasikan komputer? \\
2 & $\begin{array}{l}\text { Dalam proses pembelajaran media atau sumber belajar apa yang pernah bapak/ibu } \\
\text { gunakan? }\end{array}$
\end{tabular}


3 Berapa jumlah siswa yang aktif dalam mengikuti proses pembelajaran?

4 Berapa jumlah siswa yang cepat merasa bosan saat mengikuti proses pembelajaran dikelas?

5 Materi apa yang sulit untuk bapak/ibu jelaskan karena terlalu abstrak dan perlu dibuatkan media untuk menunjang proses pembelajaran

6 Siswa yang bapak/ibu ajar lebih tertarik belajar dengan media sederhana atau media digital?

$7 \quad$ Kendala apa saja yang bapak/ibu hadapi dalam proses pembelajaran?

Lembar wawancara digunakan untuk mengetahui informasi lebih detail mengenai media yang digunakan dalam proses pembelajaran, kendala yang dihadapi guru dan siswa dalam Guru Kelas 5 SD, dan hasil belajar siswa. Adapun kisi-kisi lembar wawancara terdapat pada tabel 2 .

Tabel 2. Kisi-kisi Lembar Wawancara

\begin{tabular}{cll}
\hline No & \multicolumn{1}{c}{ Pernyataan } & \multicolumn{1}{c}{ Sumber } \\
\hline 1 & Fasilitas apa saja yang ada di SD Negeri 1 Banjar Jawa? & Guru Kelas 5 SD \\
2 & $\begin{array}{l}\text { Bagaimanakah situasi lingkungan belajar di SD Negeri 1 } \\
\text { Banjar Jawa? }\end{array}$ & Guru Kelas 5 SD \\
3 & $\begin{array}{l}\text { Apakah ibu sering menggunakan media dalam proses } \\
\text { pembelajaran? }\end{array}$ & Guru Kelas 5 SD \\
4 & $\begin{array}{l}\text { Media apakah yang paling sering ibu gunakan dalam } \\
\text { proses pembelajaran? }\end{array}$ & Guru Kelas 5 SD \\
5 & Bagaimanakah gaya belajar siswa di kelas yang ibu ajar? & Guru Kelas 5 SD \\
6 & Apakah kendala siswa dalam mengikuti pembelajaran? & $\begin{array}{l}\text { Guru dan siswa } \\
\text { kelas 5 SD }\end{array}$ \\
7 & $\begin{array}{l}\text { Apakah siswa pernah belajar menggunakan media digital } \\
\text { seperti video, multimedia dll? }\end{array}$ & Siswa Kelas 5 SD \\
8 & Bagaimanakah hasil belajar siswa di kelas yang ibu ajar? & Guru Kelas 5 SD \\
\hline
\end{tabular}

Sebelum mengimplementasikan multimedia pembelajaran interaktif harus melakukan uji kelayakan produk terlebih dahulu oleh para ahli (ahli mata pelajaran, ahli desain pembelajaran, dan ahi media pembelajaran) dengan menggunakan lembar kuesioner, apakah multimedia yang dikembangkan layak untuk diimplementasikan atau tidak. Adapun kisi-kisi instrument dari ahli isi mata pelajaran, ahli desain pembelajaran, media pembelajaran, uji coba perorangan dan kelompok kecil dijabarkan pada tabel 3, 4, 5 dan tabel 6.

Instrumen ahli isi mata pelajaran pada penelitian pengembangan ini digunakan untuk mengetahui kualitas materi pelajaran yang terdapat dalam multimedia pembelajaran interaktif yang telah dikembangkan. Kisi-kisi instrumen ahli isi pembelajaran dalam penelitian pengembangan ini dapat dilihat pada tabel 3 .

Tabel 3. Kisi-kisi Ahli Mata Pelajaran

\begin{tabular}{cclcc}
\hline No & Aspek & \multicolumn{1}{c}{ Indikator } & $\begin{array}{c}\text { No. } \\
\text { Butir }\end{array}$ & $\begin{array}{c}\text { Jumlah } \\
\text { Butir }\end{array}$ \\
\hline 1 & Kurikulum & $\begin{array}{l}\text { Kesesuaian multimedia, indikator, dan } \\
\text { tujuan pembelajaran }\end{array}$ & $1,2,3,4$ & 4 \\
2 & Metode & $\begin{array}{l}\text { Kejelasan dan kelengkapan penyajian } \\
\text { materi, contoh, gambar, dan animasi. }\end{array}$ & $\begin{array}{c}5,6,7,8,9 \\
10\end{array}$ & 6 \\
3 & Bahasa & $\begin{array}{l}\text { Kesesuaian penggunaan bahasa dan } \\
\text { kalimat yang jelas dan tepat sesuai } \\
\text { dengan komunikasi dengan peserta } \\
\text { didik }\end{array}$ & 11,12 & 2 \\
& & & & \\
& & &
\end{tabular}




\begin{tabular}{cc}
\hline Jumlah & $\mathbf{1 5}$ \\
\hline & (Sumber:Yogiyatno, 2013)
\end{tabular}

Instrumen ahli desain pembelajaran pada penelitian pengembangan ini digunakan untuk mengetahui kualitas desain pembelajaran yang terdapat dalam multimedia pembelajaran interaktif yang telah dikembangkan. Kisi-kisi instrumen ahli desain pembelajaran dalam penelitian pengembangan ini dapat dilihat pada tabel 4 .

Tabel 4. Kisi-kisi Ahli Desain Pembelajaran

\begin{tabular}{cclcc}
\hline No & Aspek & \multicolumn{1}{c}{ Indikator } & $\begin{array}{c}\text { No. } \\
\text { Butir }\end{array}$ & $\begin{array}{c}\text { Jumlah } \\
\text { Butir }\end{array}$ \\
\hline 1 & Aspek Desain & Kejelasan dan kesesuaian rumusan & $1,2,3$, & 8 \\
& Pembelajaran & indikator, metode, lngkah-langkah, & $4,5,6$, & \\
& & teknik, instrument penilaian, dan & 7,8 & \\
\hline & & memudahkan pembelajaran & \\
\hline \multicolumn{5}{c}{ Jumlah } \\
\hline
\end{tabular}

(Sumber: APKCG PPL Real Undiksha)

Instrumen ahli media pelajaran pada penelitian pengembangan ini adalah untuk mengetahui kualitas multimedia pembelajaran interaktif yang telah dikembangkan. Kisikisi instrumen ahli isi pembelajaran dalam penelitian pengembangan ini dapat dilihat pada tabel 5.

Tabel 5. Kisi-kisi Ahli Media Pembelajaran

\begin{tabular}{|c|c|c|c|c|}
\hline No & Aspek & Indikator & No. Butir & $\begin{array}{c}\text { Jumlah } \\
\text { Butir }\end{array}$ \\
\hline 1 & Aspek Teks & $\begin{array}{l}\text { Kejelasan teks (keterbacaan teks), } \\
\text { sajian teks, ukuran dan jenis teks. }\end{array}$ & $1,2,3,4$ & 4 \\
\hline 2 & Aspek Gambar & $\begin{array}{l}\text { Tata letak gambar, kualitas, } \\
\text { keseimbangan warna dan } \\
\text { kemenarikan gambar. }\end{array}$ & $5,6,7,8,9$ & 5 \\
\hline 3 & $\begin{array}{l}\text { Aspek } \\
\text { Animasi }\end{array}$ & $\begin{array}{l}\text { Kualitas, kemenarikan, dan } \\
\text { Kesesuaian animasi dengan materi } \\
\text { yang disaijikan }\end{array}$ & $10,11,12$ & 3 \\
\hline 4 & Aspek Audio & $\begin{array}{l}\text { Kejelasan dan kesesuain penggunaan } \\
\text { suara/sound music dan narator. }\end{array}$ & $\begin{array}{l}13,14 \\
15,16\end{array}$ & 4 \\
\hline 5 & $\begin{array}{l}\text { Aspek } \\
\text { Pengemasan }\end{array}$ & $\begin{array}{l}\text { Kemenarikan dan kesesuain Cover } \\
\text { CD dengan isi media }\end{array}$ & 17,18 & 2 \\
\hline 6 & $\begin{array}{l}\text { Aspek } \\
\text { Aksesbilitas }\end{array}$ & $\begin{array}{l}\text { Kemudahan akses/penggunaan } \\
\text { multimedia pembelajaran dan } \\
\text { kelancaran link interaktif }\end{array}$ & 19,20 & 19,20 \\
\hline
\end{tabular}
Jumlah

Penggunaan instrumen uji coba perorangan dan kelompok kecil pada penelitian pengembangan ini adalah untuk mengetahui tanggapan siswa terkait dengan penggunaan multimedia pembelajaran interaktif dalam proses pembelajaran. Kisi-kisi instrumen uji coba perorangan dan kelompok kecil dalam penelitian pengembangan ini dapat dilihat pada tabel 6 . 
Tabel 6. Kisi-kisi Uji Coba Perorangan dan Kelompok Kecil

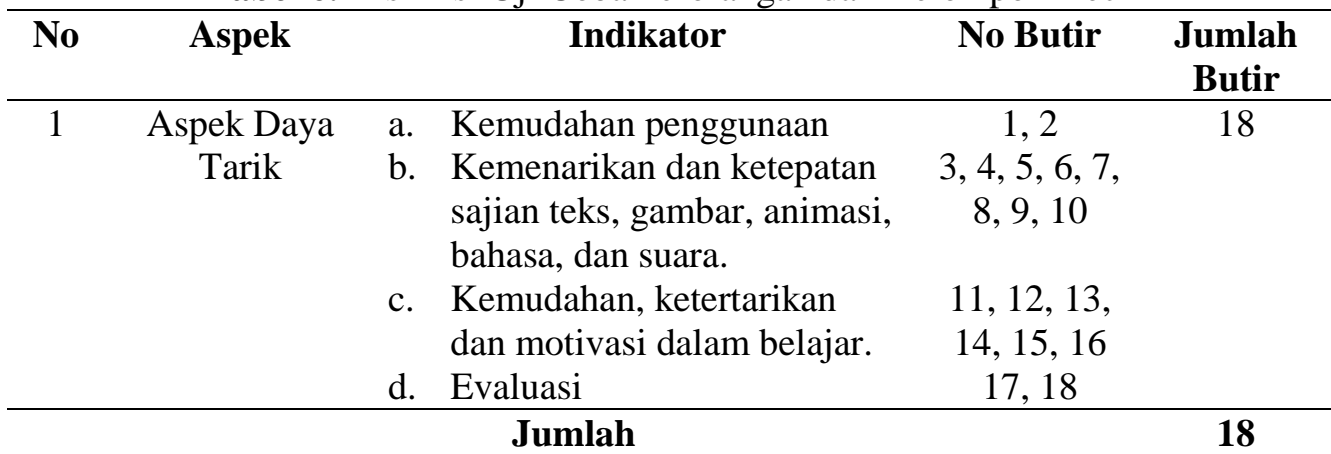

Setelah tahap pemembuat dan review oleh pakar ahli terkait empat kisi instrumen tersebut (ahli isi pelajaran, ahli desain pembelajaran, ahli media pembelajaran) dan subjek uji coba (uji coba perorangan dan kelompok kecil) selesai, tahap selanjutnya yaitu tahap mengukur validitas instrumen. Pakar yang telah melakukan penilaian instrument dengan mengklarifikasi butir instrumen, hasil penilaian akan ditabulasi dalam bentuk matrik, kemudian dilakukan perhitungan validitas isi (Retnawati, 2016:32). Pada penelitian pengembangan ini rumus yang digunakan dalam menguji validitas instrumen yaitu Rumus Gregory.

Metode analisis data yang digunakan dalam penelitian pengembangan multimedia pembelajaran interaktif ini adalah metode analisis data deskriptif kualitatif, dan metode analisis data deskriptif kuantitatif. (Agung, 2017:118) menyatakan bahwa metode analisis data deskriptif kualitatif merupakan "suatu metode pengolahan data yang sistematis dalam bentuk kalimat sehingga memperoleh kesimpulan umum". Metode ini digunakan dalam mengolah data berupa masukan, kritik dan saran dalam kuesioner digunakan dalam merevisi produk multimedia interaktif dari hasil uji coba ahli mata pelajaran, ahli desain pembelajaran, dan ahli media pembelajaran, subjek uji coba perorangan dan subjek uji coba kelompok kecil. Sedangkan metode analisis data deskriptif kuantitatif merupakan "suatu metode pengolahan data secara sistematis dalam bentuk angka untuk memperoleh kesimpulan umum" (Agung, 2017: 118). Acuan yang digunakan untuk pengambilan keputusan dalam pengembangan multimedia pembelajaran interaktif disajikan dalam tabel 7.

Tabel 7. Konversi Tingkat Pencapaian dengan Skala 5

\begin{tabular}{ccc}
\hline Tingkat Pencapaian & Kualifikasi & Keterangan \\
\hline $90 \%-100 \%$ & Sangat baik & Tidak perlu direvisi \\
$75 \%-89 \%$ & Baik & Sedikit direvisi \\
$65 \%-74 \%$ & Cukup & Direvisi secukupnya \\
$55 \%-64 \%$ & Kurang & Banyak hal yang direvisi \\
$0-54 \%$ & Sangat Kurang & Diulangi membuat produk \\
\hline
\end{tabular}

(Sumber: Tegeh dan Jampel, 2017:223)

\section{HASIL DAN PEMBAHASAN}

\section{HASIL}

Poin hasil penelitian pada penelitian pengembangan ini akan membahas mengenai dua hal yaitu: mendeskripsikan rancang bangun pengembangan multimedia pembelajaran interaktif, dan mendeskripsikan validitas pengembangan multimedia pembelajaran interaktif.

Rancang bangun pengembangan multimedia interaktif pada penelitian ini yaitu menggunakan model pengembangan ADDIE. Model ADDIE yang merupakan salah satu 
model desain pembelajaran yang sistematik (Tegeh dan Kirna, 2013). Pengembangan multimedia interaktif melewati lima tahapan. Pertama dimulai dari tahap analisis, pada tahap ini terdapat tiga hal yang perlu dianalisis yaitu (1) analisis kebutuhan, ditemukan bahwa: sebagian besar peserta didik memiliki hasil belajar yang rendah dikarenakan materi yang dibelajari bersifat abstrak sehingga susah untuk dipahami, dan kurangnya pemanfaatan media digital yang bersifat interaktif dalam proses pembelajaran; (2) analisis lingkungan, ditemukan bahwa: terdapat fasilitas yang dapat dimanfaatkan dalam menunjang proses pembelajaran seperti laptop, speaker dan LCD proyektor; dan (3) analisis materi pelajaran, ditemukan bahwa: materi siklus air sangat perlu untuk dikembangkan media pembelajaran yang menarik karena tahapan siklus air bersifat kompleks dan rumit bagi siswa SD sehingga sulit untuk dimengerti.

Tahap kedua yaitu tahap desain. Pada tahap ini hal yang dilakukan yaitu: 1) Pemilihan dan penetapan software yang akan digunakan untuk membuat multimedia interaktif ini diantaranya yaitu menggunakan aplikasi Adobe Flash Professional CS6 dibantu dengan berbagai software lainnya seperti Adobe Photoshop CS6, Microsoft Office, Corel Draw X7, Adobe Premiere Pro CS6 dan Swivel. 2) Mengembangkan flowchart untuk mendeskripsikan alur dari pengembangan produk secara keseluruhan sekaligus sebagai acuan tahapan selanjutnya. 3) Mengembangkan storyboard yang terdiri dari serangkaian sketsa yang menggambarkan suatu urutan (alur cerita) dan elemen-elemen yang diusulkan untuk aplikasi multimedia interaktif yang mencangkup penggabungan antara teks, gambar, video, animasi, serta tombol. 4) Menyusun instrument penilaian dan butir soal, serta Menyusun rancangan pelaksanaan pembelajaran (RPP) yang merujuk pada silabus.

Tahap ketiga yaitu tahap pengembangan. Pada tahap pengembangan kegiatan yang dilakukan yaitu: 1) Pengumpulan bahan dan materi. Kegiatan yang dilakukan yaitu mengumpulkan bahan-bahan dasar yang akan digunakan untuk mengembangkan multimedia interaktif seperti materi, silabus, gambar, teks, audio, video, animasi dan lain sebagainya. (2) Pengembangan multimedia pembelajaran interaktif. Setelah semua bahan terkumpul, kemudian dilanjutkan dengan pembuatan susunan kerangka multimedia yang dikembangkan terdiri dari halaman intro, profil, beranda, petunjuk, KD, materi, quis, dan evaluasi.

Tahap keempat yaitu tahap implementasi. Pada tahap implementasi, kegiatan yang dilakukan meliputi: (1) uji validasi produk oleh para ahli yang diantaranya ahli isi mata pelajaran IPA kelas V SD, ahli desain pembelajaran dan ahli media pembelajaran. (2) uji coba produk meliputi uji coba perorangan yang terdiri dari tiga orang siswa dan uji coba kelompok kecil yang terdiri dari enam orang siswa. Tujuan dilakukannya penilaian ahli dan uji coba produk yaitu untuk mengetahui kemenarikan, efektifitas produk dan kelayakan produk multimedia pembelajaran interaktif yang telah dikembangkan.

Tahap terakhir yaitu tahap evaluasi. Pada tahap ini kegiatan yang dilakukan adalah evaluasi data yang didapatan pada tahap implementasi (validitas ahli, uji coba perorangan, dan kelompok kecil). Evaluasi yang dilakukan yaitu evaluasi formatif. Evaluasi formatif adalah proses menyediakan dan menggunakan informasi untuk dijadikan dasar pengambilan keputusan dalam rangka meningkatkan kualitas produk atau program pembelajaran, Suparman (Aeni dan Yusupa, 2018). Evaluasi formatif bertujuan untuk menilai produk multimedia pembelajaran interaktif yang dikembangkan. Berdasarkan pada tahapan-tahapan tersebut, maka pengembangan multimedia pembelajaran interaktif dengan menerapkan model ADDIE dikatakan berhasil.

Tujuan dilakukannya uji validitas pengembangan multimedia pembelajaran interaktif adalah untuk menguji tingkat kelayakan terkait penggunaan multimedia pembelajaran interaktif dalam proses pembelajaran. Instrumen yang digunakan dalam mengetahui validitas produk yaitu berupa kuesioner. Validitas butir-butir instrumen akan diujikan oleh judges yang berkompeten. Adapun hasil dari validitas uji instrumen yang telah yang telah dilakukan, disajikan pada tabel 8 . 
Tabel 8. Hasil dari Uji Validitas Instrumen

\begin{tabular}{ccc}
\hline Jenis Validitas & Hasil & Kualifikasi \\
\hline Validitas Isi & 1 & Sangat Tinggi \\
Validitas Desain & 1 & Sangat Tinggi \\
Validitas Media & 1 & Sangat Tinggi \\
Validitas Uji Coba Produk & 1 & Sangat Tinggi \\
\hline
\end{tabular}

Berdasarkan data pada tabel 8 menunjukkan bahwa: 1) Hasil validitas instrumen isi mata pelajaran oleh judges mendapatkan nilai 1 dengan kriteria kualifikasi sangat tinggi. 2) Hasil validitas instrumen desain pembelajaran mendapatkan nilai 1 dengan kriteria kualifikasi sangat tinggi. 3) Hasil validitas instrumen media pembelajaran mendapatkan nilai 1 dengan kriteria kualifikasi sangat tinggi. 4) Hasil validitas intrumen uji coba produk juga mendapatkan kriteria kualifikasi sangat tinggi. Setelah melakukan uji validitas instrumen, tahap selanjutnya yaitu melakukan penilaian oleh para ahli (ahli isi mata pelajaran, ahli desain pembelajaran, ahli media pembelajaran. Adapun hasil dari penilaian tersebut disajikan pada tabel 9 .

Tabel 9. Hasil Uji Validitas Produk

\begin{tabular}{cccc}
\hline No & \multicolumn{1}{c}{ Subjek Uji Coba } & Hasil Validitas (\%) & Keterangan \\
\hline 1. & Uji Ahli Isi Mata Pelajaran & $97,33 \%$ & Sangat Baik \\
2. & Uji Ahli Desain Pembelajaran & $100 \%$ & Sangat Baik \\
3. & Uji Ahli Media Pembelajaran & $98 \%$ & Sangat Baik \\
4 & Uji Coba Perorangan & $96,67 \%$ & Sangat Baik \\
5 & Uji Coba Kelompok Kecil & $96,85 \%$ & Sangat Baik \\
\hline
\end{tabular}

Penilaian produk multimedia pembelajaran interaktif yang dilakukan oleh ahli isi mata pelajaran IPA, dengan menggunakan metode pengumpulan data kuesioner, mendapatkan hasil presentase pencapaian 97,33\% dengan kualifikasi sangat baik, penilaian tersebut dikonversi melalui tingkat pencapaian skala 5. Penilaian produk multimedia pembelajaran interaktif yang dilakukan oleh ahli desain pembelajaran, dengan menggunakan metode pengumpulan data kuesioner, mendapatkan hasil presentase pencapaian $100 \%$ dengan kualifikasi sangat baik, penilaian tersebut dikonversi melalui tingkat pencapaian skala 5. Penilaian produk multimedia pembelajaran interaktif yang dilakukan oleh media pembelajaran, dengan menggunakan metode pengumpulan data kuesioner, mendapatkan hasil presentase pencapaian 98\% dengan kualifikasi sangat baik, penilaian tersebut dikonversi melalui tingkat pencapaian skala 5. Uji coba perorangan dan kelompok kecil dilakukan dengan menggunakan metode pengumpulan data kuesioner, mendapatkan hasil presentase pencapaian $96,76 \%$ dengan kualifikasi sangat baik, penilaian tersebut dikonversi melalui tingkat pencapaian skala 5.

Berdasarkan pada prolehan hasil diatas, maka dapat disimpukan bahwa multimedia pembelajaran interaktif dapat dinyatakan layak untuk digunakan dalam proses pembelajaran dan tidak perlu direvisi. Masukan yang diberikan oleh ahli isi mata pelajaran, ahli desain pembelajaran, dan ahli media pembelajaran dipertimbangkan dalam menyempurnakan pengembangan multimedia pembelajaran interaktif yang dikembangkan. Adapun masukan dan saran produk multimedia pembelajaran interaktif dari ahli desain pembelajaran disajikan pada tabel 10 .

Tabel 10. Komentar, Saran dan Perbaikan Produk Ahli Mata Pelajaran IPA

\begin{tabular}{cccccc}
\hline No & \multicolumn{4}{c}{ Komentar dan Saran } & Revisi \\
\hline 1. & Isi & materi & yang & terkandung & didalam \\
\hline
\end{tabular}


multimedia sudah sesuai dengan kompetensi

dasar, indikator dan tujuan pembelajaran.

Pengemasan materi dalam bentuk

multimedia sangat bagus dan menarik.

Berdasarkan pada masukan yang diberikan oleh ahli desain pembelajaran, dilakukan perbaikan terkait dengan penyempurnaan produk multimedia pembelajaran interaktif. Adapun masukan dan saran produk multimedia pembelajaran interaktif dari ahli desain pembelajaran disajikan pada tabel 11.

Tabel 11. Komentar, Saran dan Perbaikan Produk Ahli Desain Pelajaran

\begin{tabular}{cll}
\hline No & \multicolumn{1}{c}{ Komentar dan Saran } & \multicolumn{1}{c}{ Revisi } \\
\hline 1. & $\begin{array}{l}\text { Pada halaman profil tanda panah } \\
\text { tombol kembali dibalik dari menghadap } \\
\text { kekanan menjadi menghadap kekiri. }\end{array}$ & $\begin{array}{l}\text { Arah tanda panah tombol kembali } \\
\text { sudah dibalik dari menghadap } \\
\text { kekanan menjadi menghadap kekiri. }\end{array}$ \\
2. & $\begin{array}{l}\text { Perbaiki kata yang salah ketik pada } \\
\text { halaman petunjuk pembelajaran. }\end{array}$ & $\begin{array}{l}\text { Kesalahan pengetikan kata sudah di } \\
\text { perbaiki. }\end{array}$ \\
\hline
\end{tabular}

Berdasarkan pada masukan yang diberikan oleh ahli media pembelajaran, dilakukan perbaikan terkait dengan penyempurnaan produk multimedia pembelajaran interaktif. Adapun masukan dan saran produk multimedia pembelajaran interaktif dari ahli media pembelajaran disajikan pada tabel 12 .

Tabel 12. Komentar, Saran dan Perbaikan Produk Ahli Media Pelajaran

\begin{tabular}{ccc}
\hline No & Komentar dan Saran & \multicolumn{1}{c}{ Revisi } \\
\hline 1. & $\begin{array}{l}\text { Tambahkan kelas, semester, dan } \\
\text { topik yang akan dipelajari pada } \\
\text { halaman beranda. }\end{array}$ & $\begin{array}{l}\text { Identitas kelas, semester, dan topik yang } \\
\text { akan dipelajari sudah halaman beranda. }\end{array}$ \\
2. & $\begin{array}{l}\text { Perjelas petunjuk pembelajaran. } \\
\text { Petunjuk pembelajaran sudah diperjelas } \\
\text { sesuai dengan karakteristik multimedia. }\end{array}$ \\
\hline
\end{tabular}

Hasil dari pengembangan multimedia pembelajaran interaktif pada penelitian pengembangan ini disajikan pada gambar 1, 2, 3, 4 .

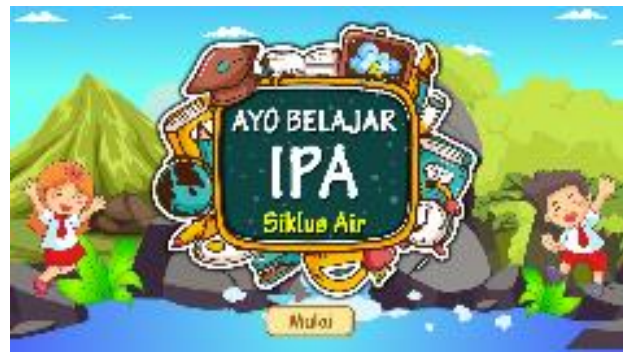

Gambar 1. Halaman Intro

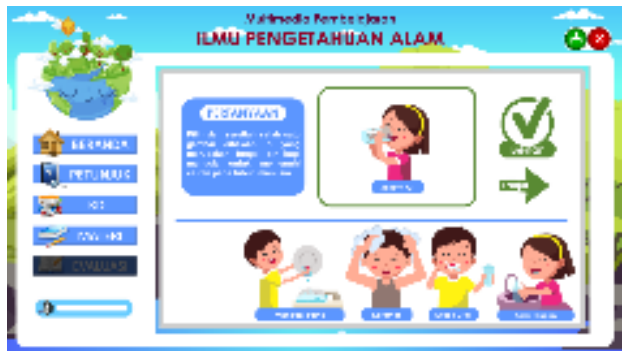

Gambar 3. Halaman Quis

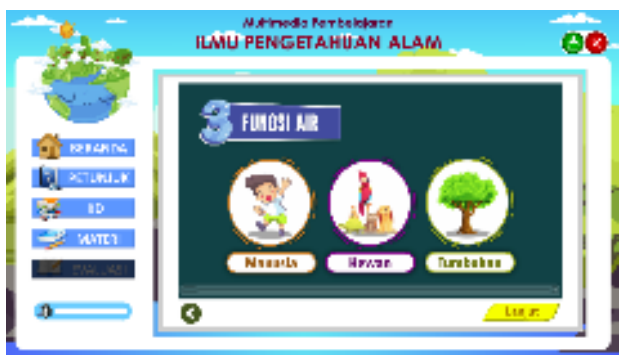

Gambar 2. Halaman Materi

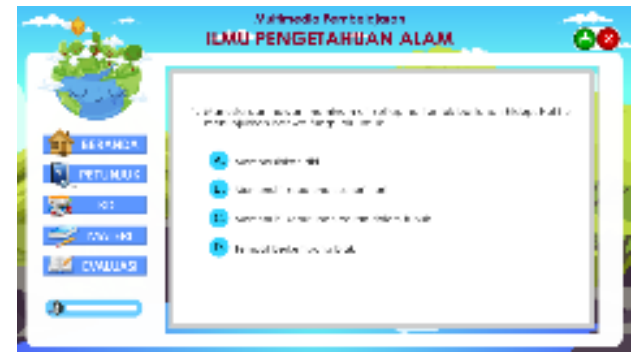

Gambar 4. Halaman Evaluasi 


\section{PEMBAHASAN}

Merujuk pada data hasil uji validitas yang telah dilakukan, pengembangan multimedia pembelajaran interaktif menunjukan kualifikasi yang sangat baik dari penilaian para ahli, dan hasil uji coba peroduk sehingga multimedia pembelajaran interaktif yang dikembangkan dinyatakan layak digunakan dalam proses pembelajaran. Hal ini juga dikarenakan proses pengembangan multimedia pembelajaran interaktif menggunakan model pengembangan yang tepat dan sistematis sehingga dapat meminimalisir terjadinya kesalahan dalam proses pengembangan sejak awal. Pengembangan multimedia pembelajaran interaktif pada penelitian pengembangan ini menggunakan model pengembangan ADDIE yang melewati beberapa tahap seperti tahap analisis, desain, pengembangan, implementasi dan terakhir evaluasi sehingga pengembangan yang dilakukan menjadi lebih terstruktur, hal tersebutlah yang menyebabkan multimedia pembelajaran interaktif menjadi lebih efektif digunakan dalam proses pembelajaran selaian dari karakteristik multimedia itu sendiri.

Merujuk pada hasil penilaian yang telah diberikan oleh ahli isi mata pelajaran IPA terhadap produk multimedia pembelajaran interaktif yang telah dikembangkan mendapatkan hasil kualifikasi sangat baik. Berdasarkan kuisioner instrumen penilaian ahli isi mata pelajaran IPA yang terdiri dari lima belas indikator penilai. Penilaian tersebut mendapatkan hasil yaitu dengan tiga belas indikator mendapatkan skor dengan kualifikasi sangat baik dan dua indikator mendapatkan skor dengan kualifikasi baik. Kualifikasi sangat baik pada setiap indikator dapat tercapai disebabkan oleh karena beberapa poin penting yaitu: (1) indikator, kompetensi dasar dan tujuan pembelajaran yang terdapat pada multimedia pembelajaran interaktif sudah sesuai dengan karakteristik pembelajaran dan kopetensi yang dimiliki siswa, (2) Materi yang disajikan dalam multimedia pembelajaran interaktif sudah jelas dan runtut serta diperkuat dengan penyediaan contoh-contoh seperti gambar, video, dan animasi yang sesuai dengan materi pembelajaran, (3) penggunaan kalimat dan bahasa dalam multimedia pembelajaran interaktif sudah jelas dan sesuai dengan bahasa komunikasi peserta didik, (4) tingkat kesulitan soal dan kesesuaian soal evaluasi dengan tujuan pembelajaran sudah sesuai. Hal ini juga diperkuat dengan pernyataan dari Arsyad (Dwiningsih, dkk, 2018) mengungkapkan bahwa suatu media pembelajaran harus memiliki fokus yang jelas pada tujuan pembelajaran, indikator dan kompetensi dasar siswa. (Krissandi dan Rusmawan, 2015) juga menegaskan bahwa kejelasan dan keterkaiatan antara media pembelajaran dengan indikator, tujuan, dan materi, harus menjadi perhatian dan pertimbangan pengajar untuk memilih dan menggunakan media dalam proses pembelajaran di kelas sehingga media yang digunakan lebih efektif dan efisien untuk mencapai tujuan pembelajaran. Selain itu Sadiman (Afandi, 2015) juga mengemukakan prinsip-prinsip dalam mengevaluasi media pembelajaran yaitu: (1) media pengajaran harus sesuai dengan tujuan pembelajaran, (2) kosakata (3) kesesuaian dengan isi materi, (4) kesesuaian dengan berbagai jenis siswa (karakteristik siswa), dan (5) Kualitas gambar atau visual. Berdasarkan pada pernyataan-pernyataan tersebut maka dapat disimpulkan bahwa kejelasan dan keterkaitan indikator, kompetensi dasar, tujuan pembelajaran, sajian materi, penggunaan bahasa, serta kesesuaian evaluasi dengan tujuan pembelajaran yang terkandung didalam multimedia pembelajaran interaktif akan mampu memfasilitasi guru dan siswa dalam pembelajaran sehingga akan berdampak positif bagi hasil belajar siswa, dengan demikian tujuan pembelajaran akan dapat tercapai dengan maksimal. 
Merujuk pada hasil penilaian yang telah diberikan oleh ahli desain pelajaran terhadap produk multimedia pembelajaran interaktif yang telah dikembangkan mendapatkan hasil kualifikasi sangat baik. Berdasarkan kuisioner instrumen penilaian ahli isi mata pelajaran IPA yang terdiri dari delapan indikator penilai dan pada hasil penilaian ahli desain ini seluruh poin indikator mendapatkan kualifikasi sangat baik. Hal ini disebabkan karena beberapa poin penting yaitu: (1) rumusan indikator yang terkandung dalam multimedia sudah sesuai dengan indikator pembelajaran; (2) materi pembelajaran yang terkandung dalam multimedia sudah jelas; (3) metode, langkah-langkah pembelajaran, teknik penilaian, dan instrument penilaian yang digunakan dalam mengaplikasikan multimedia dalam pembelajaran sudah sesuai; (4) ketepatan dalam pemilihan media sehingga memudahkan dalam pembelajaran. Hal ini diperkuat dengan penelitian yang dilakukan oleh (Lukum, 2015) yang menyatakan bahwa perencanaan pembelajaran yang baik akan dapat mempermudah proses pembelajaran sehingga proses pembelajaran dapat berjalan dengan maksimal, serta adanya evaluasi pembelajaran akan bermanfaat untuk mengetahui pemahaman siswa dalam proses belajar. Perancangan pembelajaran melibatkan beberapa aspek seperti: media, metode pembelajaran dan pendekatan pembelajaran. Berdasarkan pada pernyataan-pernyataan tersebut maka dapat disimpulkan bahwa desain pembelajaran yang sesuai dengan karakteristik pembelajaran dan peserta didik akan lebih efektif untuk memudahkan siswa dalam pembelajaran sehingga akan berdampak positif bagi hasil belajar siswa, dengan demikian tujuan pembelajaran akan dapat tercapai dengan maksimal.

Berdasarkan pada hasil penilaian yang telah diberikan oleh ahli media pembelajaran terhadap produk multimedia pembelajaran interaktif yang telah dikembangkan mendapatkan hasil kualifikasi sangat baik. Kuisioner instrumen penilaian ahli media pembelajaran terdiri dari dua puluh indikator penilai. Penilaian tersebut mendapatkan hasil yaitu dengan delapan belas indikator mendapatkan skor dengan kualifikasi sangat baik dan dua indikator mendapatkan skor dengan kualifikasi baik. Kualifikasi sangat baik pada setiap indikator dapat tercapai disebabkan oleh karena beberapa poin penting yaitu: (1) ketepatan dan keterbacaan teks baik dari segi ukuran, jenis ataupun tata letak teks; (2) kesesuaian penggunaan gambar dan keseimbangan warna yang disajikan dalam multimedia dengan materi pembelajaran; (3) kesesuaian dan kemenarikan video dan animasi yang disajikan dalam multimedia dengan materi; (4) kesesuaian dan kejelasan suara baik itu backsound, sound effect ataupun penjelasan narrator dengan materi; (5) kemudahan dalam penggunaan multimedia; dan (6) interaktivitas multimedia dalam pembelajaran. (Sudarma, dkk, 2015) menyatakan interaktivitas mengasumsikan bahwa siswa dapat belajar lebih baik ketika ia mengendalikan sendiri apa yang sedang dipelajarinya, oleh karena itu multimedia pembelajaran harus memungkinkan siswa mengendalikan multimedia. Hal ini diperkuat dengan hasil penelitian Leow (Arham dan Dwiningsih, 2016) menyatakan bahwa selain memperdalam pemahaman siswa, unsur-unsur dalam media seperti video dan animasi membantu siswa mendapatkan informasi yang lebih rinci sehingga kapasitas untuk tersimpan dalam memori otak juga meningkat. Berdasarkan pada pernyataan-pernyataan tersebut maka dapat disimpulkan bahwa media yang memadukan banyak unsur didalamnya salah satunya interaktivitas dapat membuat proses pembelajaran lebih menarik dan efektif karena melibatkan lebih dari satu indra dalam belajar sehingga dapat merangsang siswa dalam pembelajaran dan akan berdampak positif bagi hasil belajar siswa, dengan demikian tujuan pembelajaran akan dapat tercapai dengan maksimal.

Penggunaan multimedia dalam pembelajaran tentunya akan lebih mampu menarik perhatian peserta didik sehingga lebih mudah dalam memahami materi. Hal ini sejalan dengan pendapat Munir (Candra dan Masruri, 2015) yang menyatakan bahwa penggunaan 
multimedia interaktif dapat membantu peserta didik memahami materi yang diajarkan melalui pola penyajian yang menarik, mudah dipahami, dan menyenangkan. (Sitompul, dkk, 2017) juga menegaskan bahwa penggunaan multimedia pembelajaran berbasis komputer juga dapat membuat pembelajar untuk lebih mengingat materi yang dipelajari. Hal tersebut sejalan dengan pendapat dari (Pangaribuan dan Saragih, 2014) yang menyatakan bahwa penggunaan multimedia pembelajaran interaktif dalam proses belajar juga akan membuat suasana yang berbeda dalam pembelajaran, karena materi yang dulunya diajarkan dengan ceramah dan hanya monoton dapat divariasi dengan menampilkan tayangan berupa integrasi teks, suara, gambar bergerak dalam multimedia interaktif tersebut. Karena manfaat dan kelebihan multimedia pengajaran menurut Arsyad, Aster dan Suyanto (Susiana dan Wening, 2015) yaitu motivasi dan perhatian siswa dapat ditingkatkan melalui multimedia, pembelajaran lebih menarik bagi siswa, meningkatkan hasil pembelajaran dan mempersingkat waktu penyajian pembelajaran.

Pernyataan tersebut diperkuat dengan penelitian yang dilakukan oleh (Jannah, dkk, 2020) menyatakan bahwa penggunaan multimedia dalam proses pembelajaran sangat efektif. Dengan penggunaan multimedia dalam proses pembelajaran akan menumbuhkan suasana belajar yang nyaman dan menarik, sehingga siswa akan lebih tertarik dalam proses pembelajaran serta siswa akan lebih memahami materi yang diberikan. Penggunaan Multimedia Interaktif terbukti dapat meningkatkan motivasi dan hasil belajar siswa, (Fauziah, dkk, 2016). Hasil penelitian (Nurlaela, dkk, 2016) juga menyatakan bahwa penggunaan multimedia interaktif sangat besar potensinya untuk digunakan dalam proses pembelajaran pada masa yang akan datang, sebab penggunaan multimedia interaktif akan mampu mengintegrasikan pengetahuan yang diperoleh siswa dengan kehidupan nyata di lingkungan para siswa. Berdasarkan penelitian tersebut maka dapat disimpulkan bahwa multimedia pembelajaran interaktif memiliki potensi yang besar dan layak digunakan untuk kedepannya dalam proses pembelajaran karena pembelajaran menjadi lebih menarik dan interaktif sehinga dapat meningkatkan hasil belajar siswa.

Berdasarkan pada hasil penilaian yang telah diberikan oleh ahli media pembelajaran terhadap produk multimedia pembelajaran interaktif yang telah dikembangkan mendapatkan hasil kualifikasi sangat baik. Kualifikasi sangat baik pada setiap indikator dapat tercapai disebabkan oleh karena beberapa poin penting yaitu: (1) kemudahan penggunaan multimedia pembeljaran interaktif; (2) kemenarikan tampilan multimedia baik dari segi teks, warna, gambar, animasi, video, dan audio; (3) kejelasan sajian materi dan penyertaan contoh-contoh; dan (4) mampu memotivasi siswa dalam belajar. Hal ini sejalan dengan penelitian yang dilakukan oleh (Setyaningsih, dkk, 2019) menyatakan bahwa kemudahan mengakses atau menggunakan media akan dapat membuat siswa lebih sering membuka kembali materi yang disampaikan diluar jam pelajaran. Selain itu (Sudarma, dkk, 2015) juga menyatakan bahwa tampilan media pembelajaran yang menarik dapat memotivasi siswa dalam belajar, serta bahasa komunikatif dapat membuat siswa lebih mudah memahami materi pembelajaran.Berdasarkan pada pernyataan-pernyataan tersebut maka dapat disimpulkan bahwa kemudahan penggunaan, tampilan menarik, dan kejelasan sajian materi akan mampu meningkatkan motivasi belajar siswa sehingga akan berdampak positif terhadap hasil belajar siswa. Dengan adanya kombinasi penggunaan media digital dalam proses pembelajaran akan sangat menguntunggan dalam menjembatani proses penyampaian materi kepada siswa selain pembelajaran akan menjadi lebih inovatif. 


\section{SIMPULAN}

Berdasarkan pada pemaparan diatas dapat disimpulan bahwa penelitian pengembangan Multimedia Pembelajaran Interaktif dengan model pengembangan ADDIE melalui lima tahapan pengemban yaitu (1) tahap analyze, (2) tahap design, (3) tahap development: (4) tahap implementation, (5) tahap evaluation. Merujuk pada tahapantahapan pengembangan tersebut pengembangan Multimedia Pembelajaran Interaktif berada pada kualifikasi sangat baik dan layak digunakan untuk menunjang proses pembelajaran di kelas. Penggunaan Multimedia Pembelajaran Interaktif dalam proses pembelajaran sangat efektif untuk menarik minat siswa dalam belajar dan pembelajaran menjadi lebih interaktif sehingga dapat meningkatkan hasil belajar siswa secara signifikan.

\section{DAFTAR PUSTAKA}

Abdullah, R. (2016). Pembelajaran Dalam Perspektif Kreativitas Guru Dalam Pemanfaatan Media Pembelajaran. Lantanida Journal, 4(1), 35-49.

Aeni, W. A., dan Yusupa, A. (2018). Model Media Pembelajaran E-Komik Untuk Sma E-Komik Learning Media Model For Senior High School. Jurnal Teknologi Pendidkan, 06(01), 43-59.

Afandi, R. (2015). Pengembangan Media Pembelajaran Permainan Ular Tangga Untuk Meningkatkan Motivasi Belajar Siswa Dan Hasil Belajar Ips Di Sekolah Dasar. Jinop Jurnal Inovasi Pembelajaran, 1(1), 77-89.

Agung, A. A. G. (2017). Buku Ajar Metodologi Penelitian. Aditya Media.

Arham, U. U., dan Dwiningsih, K. (2016). Keefektifan Multimedia Interaktif Berbasis Blended Learning Untuk Meningkatkan Hasil Belajar Siswa. Kwangsan, 4(2), 111-118.

Bardi, dan Jailani. (2015). Pengembangan Multimedia Berbasis Komputer Untuk Pembelajaran Matematika Bagi Siswa Sma. Jurnal Inovasi Teknologi Pendidikan, 2(1), 49-63.

Candra, A. A., dan Masruri, M. S. (2015). Pengembangan Multimedia Interaktif Dengan Pendekatan Saintifik Untuk Pembelajaran Pkn SMP. Jural Pendidikan Ips, 2(2), 109-114.

Dwiningsih, K., dkk. (2018). Pengembangan Media Pembelajaran Kimia Menggunakan Media Laboratorium Virtual Berdasarkan Paradigma Pembelajaran Di Era Global. Jurnal Teknologi Pendidikan, 06(02), 156-176.

Elpira, N., dan Ghufron, A. (2015). Pengaruh Penggunaan Media Powerpoint Terhadap Minat Dan Hasil Belajar Ipa Siswa Kelas Iv Sd. Jurnal Inovasi Teknologi Pendidikan, 2(1), 94-104.

Fauziah, F., dkk. (2016). Efektivitas Penggunaan Multimedia Interaktif Terhadap Motivasi Dan Hasil Belajar Siswa Di SMP Pada Mata Pelajaran Ips. Jurnal Teknologi Pendidikan Dan Pembelajaran, 1(1), 26-37.

Jannah, I. N., dkk. (2020). Efektivitas Penggunaan Multimedia Dalam Pembelajaran Ipa Di Sd. Jurnal Ilmiah Sekolah Dasar, 4(1), 54-59.

Jumasa, M. A., dan Surjono, H. D. (2016). Pengembangan Multimedia Pembelajaran Bahasa Inggris Untuk Pembelajaran Teks Recount Di Mtsn II Yogyakarta. Jurnal Inovasi Teknologi Pendidikan, 3(1), 25-39.

Krissandi, A. D. S., dan Rusmawan. (2015). Kendala Guru Sekolah Dasar Dalam Implementasi Kurikulum 2013. Cakrawala Pendidikan, 34(3), 457-467.

Lukum, A. (2015). Evaluasi Program Pembelajaran Ipa Smp Menggunakan Model 
Countenance Stake. Jurnal Penelitian Dan Evaluasi Pendidikan, 19(1), 25-37.

Nazalin, dan Muhtadi, A. (2016). Pengembangan Multimedia Interaktif Pembelajaran Kimia Pada Materi Hidrokarbon Untuk Siswa Kelas Xi Sma. Jurnal Inovasi Teknologi Pendidikan, 3(2), 221-236.

Nugraha, A. N. C., dan Muhtadi, A. (2015). Pengembangan Multimedia Pembelajaran Matematika Pada Materi Bangun Ruang Sisi Datar Untuk Siswa Smp Kelas Viii. Jurnal Inovasi Teknologi Pendidikan, 2(1), 16-31.

Nurlaela, Wahyudin, dan Hamdani, N. A. (2016). Efektivitas Penggunaan Multimedia Pembelajaran Interaktif Melalui Pendekatan Ctl Dalam Meningkatkan Hasil Belajar Siswa Tentang Pesawat Sederhana Pada Pembelajaran Ipa Di Kelas V Sekolah Dasar Negeri Hanjuang I. Jurnal Teknologi Pendidikan Dan Pembelajaran, 1(1), 48-59.

Pangaribuan, F. A., dan Saragih, A. H. (2014). Pengembangan Multimedia Pembelajaran Interaktif Mata Kuliah Seni Lukis I Jurusan Seni Rupa. Jurnal Teknologi Informasi \& Komunikasi Dalam Pendidikan, 1(1), 75-86.

Putra, L. D., dan Ishartiwi. (2015). Pengembangan Multimedia Pembelajaran Interaktif Mengenal Angka Dan Huruf Untuk Anak Usia Dini. Jurnal Inovasi Teknologi Pendidikan, 2(2), 169-178.

Putri, D. P. E., dan Muhtadi, A. (2018). Pengembangan Multimedia Pembelajaran Interaktif Kimia Berbasis Android Menggunakan Prinsip Mayer Pada Materi Laju Reaksi. Jurnal Inovasi Teknologi Pendidikan, 5(1), 38-47.

Retnawati, H. (2016). Analisis Kuantitatif Instrmen Penelitian (Panduan Penelti,Mahasiswa, Dan Psikometrian). Parama Publishing.

Riyadi, S., dan Pardjono. (2014). Pengembangan Multimedia Pembelajaran Matematika Berbasis Komputer Untuk Kelas VIII SMP. Jurnal Inovasi Teknologi Pendidikan, 1(2), 165-177.

Rosita, F. Y. (2015). Pengembangan Multimedia Interaktif Untuk Pembelajaran Berbicara Bagi Siswa Kelas Iv Sekolah Dasar. Jinop Jurnal Inovasi Pembelajaran, 1(1), 25-37.

Rusdewanti, P. P., dan Gafur, A. (2014). Pengembangan Media Pembelajaran Interaktif Seni Musik Untuk Siswa Smp. Jurnal Inovasi Teknologi Pendidikan, 1(2), 153-164.

Setyaningsih, G., dkk. (2019). Penerapan Aplikasi Media Pembelajaran Pada Smp N 1 Nusawungu Berbasis Smartphone Android. Jurnal Matrik, 18(2), 246-256. https://doi.org/https://doi.org/10.30812/matrik.v18i2.365

Sitompul, H., dkk. (2017). Pengaruh Media Pembelajaran Dan Motivasi Belajar Terhadap Hasil Belajar Desain Sistem Instruksional Pendekatan Tpack. Jurnal Teknologi Informasi Dan Komunikasi Dalam Pendidikan, 4(2), 141-146.

Sudarma, I. K., dkk. (2015). Desain Pesan Kajian Analistis Desain Visual. Graha Ilmu.

Sudatha, I. G. W. (2015). Desain Multimedia Pembelajaran. Media Akademi.

Surya, Y. F. (2017). Penerapan Model Pembelajaran Problem Based Learning Untuk Meningkatkan Hasil Belajar Matematika Siswa Kelas Iv Sdn 016 Langgini Kabupaten Kampar. Jurnal Pendidikan Matematika, 1(1), 38-53.

Susiana, R., dan Wening, S. (2015). Pengaruh Model Direct Instruction Berbantuan Multimedia Terhadap Motivasi Belajar Dan Pencapaian Kompetensi Pembuatan Desain Busana. Jurnal Pendidikan Vokasi, 5(3), 377-393.

Tegeh dan Jampel. (2017). Metode Penelitian Pengembangan. Universitas 
Pendidikan Ganesha.

Tegeh, I. M., dan Kirna, I. M. (2013). Pengembangan Bahan Ajar Metode Penelitian Pendidikan Dengan Addie Model. Jurnal Ika, 11(1), 12-26.

Trisiana, A., dan Wartoyo. (2016). Desain Pengembangan Model Pembelajaran

Pendidikan Kewarganegaraanmelalui Addie Model Untuk Meningkatkan Karaktermahasiswa Di Universitas Slamet Riyadi Surakarta. Pkn Progresif, 11(1), 312-329.

Uno, H. B., dan Ma'ruf, A. R. K. (2016). Pengembangan Media Pembelajaran IPS Berbasis Website Untuk Siswa Kelas Vii Madrasah Tsanawiyah Negeri. Jurnal Teknologi Pendidikan, 18(3), 169-185.

Widiara, I. K. (2018). Blended Learning Sebagai Alternatif Pembelajaran Di Era Digital. Jurnal Purwadita, 2(2), 50-56.

Widyatmojo, G., dan Muhtadi, A. (2017). Pengembangan Multimedia Pembelajaran Interaktif Berbentuk Game Untuk Menstimulasi Aspek Kognitif Dan Bahasa Anak Tk. Jurnal Inovasi Teknologi Pendidikan, 4(1), 38-49.

Yogiyatno, W. (2013). Pengembangan Multimedia Interaktif Kompetensi Dasar Mengoperasikan Software Basis Data Untuk Smk Negeri 1 Seyegan. Jurnal Pendidikan Vokasi, 3(3), 391-404. 